This is an Accepted Manuscript of an article published by Taylor \& Francis in Journal of Heritage Tourism on January 12, 2017, available online: http://www.tandfonline.com/doi/full/10.1080/1743873X.2016.1277732?scroll=t op\&needAccess $=$ true

Child's play at war memorials: insights from a social media debate

Rebecca H. Price (corresponding author) rebecca.price@pitt.edu

Mary Margaret Kerr 


\section{Child's play at war memorials: insights from a social media debate}

Each year, thousands of children visit memorials and other heritage sites during family or school trips, yet heritage scholars possess little understanding of their experiences. Despite its absence from the scholarly literature, children's exploratory play at war memorials recurs frequently in the popular media. Extensive social media interest suggests that public sentiment, often emotional and vividly expressed, deserves study as a potential influence on children's experiences at these and other dark heritage sites. This paper provides new insights of behavioral expectations for children at memorials, based on content analysis of 150 comments on a viral social media post picturing children playing on the Vietnam Women's Memorial in Washington DC. Conducting a stance analysis of comments, we considered commenters' behavioral expectations, meanings they ascribed to memorials, and rationales for their intensely worded positions. Commenters shared several values: that memorials represented soldiers' sacrifice, veterans' service, general places for respect or to do what is right, or artistic value. Yet despite these shared rationales, many commenters expressed polarized opinions of children's play at memorials. Commenters also referenced memorials and battlefields worldwide. This study provides greater understanding of the cultural context of children's visits to memorials and other sites of painful heritage.

Keywords: heritage; dark tourism; social media; children; memorials 


\section{Child's play at war memorials: insights from a social media debate}

Each year, thousands of children travel during family or school trips (Kerr \& Price, 2016). Yet, heritage scholars possess little understanding about child tourists (Khoo-Lattimore, 2015; Poria \& Timothy, 2014; Small, 2008) and even less about how children explore dark sites, those associated with "death, suffering, and the seemingly macabre" (Stone, 2006, p. 146).

Despite its absence in the scholarly literature, children's exploratory play at war memorials recurs frequently in the popular media. Lately, children's news-making behavior has included climbing on sculptures, wading in fountains, and playing Pokémon Go at Holocaust museums (see Bromwich, 2016; "Facebook rant," 2015; MyFoxDC.com Web Producer, 2015). One photo of children playing in a World War II memorial fountain was shared more than 40,000 times in just a few days ("Facebook rant," 2015). Such extensive social media interest suggests that public sentiment, often strongly emotional and vividly expressed, deserves study as a potential influence on children's experiences at dark heritage sites.

In March 2015, a tourist from Ohio snapped a photograph in Washington, D.C., which when posted online sparked a "huge response" and "outraged" comments (MyFoxDC.com Web Producer, 2015). Presented as Figure 1, this photograph depicts young children climbing on the Vietnam Women's Memorial, in view of an elderly man and his companions. The debate sparked by this picture "went viral," receiving mentions on national news sites such as CNN (Pearson, 2015).

(Figure 1)

In this study, we analyzed the most popular social media comments about this photograph. Specifically we sought to answer two questions: 1) What might this debate tell us 
about public views on children's behavior at war memorials? 2) What do commenters' rationales tell us about the meaning of war memorials? Before presenting an analysis of these comments, we first consider the larger context of heritage tourism and dark tourism, as this case study situates itself in that literature. We also comment on prior research on children's exploratory play at memorials and other heritage sites. We then review prior research on social media commentary as insight into both tourist experience and into controversial topics.

\section{Relevant literature}

Adults view war memorials and related sites as critical for children to visit, so that they may pass on the history that the sites represent (Kerr \& Price, 2016; Poria, Reichel, \& Biran, 2006). Travel to such heritage sites may be considered dark tourism, a term introduced by Foley and Lennon (1996) and referring primarily to the destinations themselves (see also Timothy \& Boyd, 2006). Although recently defined, the practice of dark tourism existed long before scholars gave it a name (Hartmann, 2014; Seaton, 1996). Once designated as a topic of study, the focus expanded to include visitors' motivations, including the desire to actually or symbolically confront death, known as thanatourism (Seaton, 1996; Wight \& Lennon, 2002). More recently, a focus on heritage emerged with associated references to "heritage that hurts" or "painful heritage" (Sather-Wagstaff, 2011; Uzzell \& Ballantyne, 2008) and “dark heritage" (Biran, Poria, \& Oren, 2011). [For a detailed history, see Ashworth \& Isaac, 2015; Hartmann, 2014.] After years of conceptual and definitional debates, the concept of dark tourism "remains loosely defined," according to Ashworth and Isaac (2015, p. 9).

Throughout these scholarly controversies, one conclusion remains clear: we know virtually nothing about children's experiences when they visit such destinations. Moreover, for reasons we outline here, prior research exclusively with adult visitors cannot explain children's 
encounters. Frost and Laing (2016) claim that "research is needed to explore whether there are particular ways in which heritage is presented to or consumed by children, which are different from an adult audience" (p. 3). Applying this to war memorials, children's experiences might differ from those of adults in several dimensions. First, children may lack motivation to engage with a destination they did not choose, finding ways to amuse themselves (e.g., talking, playing, using electronics). Second, children may lack a complete understanding of death and thereby not grasp the solemnity of a memorial. Third, children's exploration may include playful behavior (Kerr \& Price, in press). Fourth, children's explorations could be influenced by other visitors, including other children who encourage play or adults who either condone or disapprove their behavior. Finally, the design of the space or exhibits might hint to children that certain behavior is appropriate or allowed.

\section{Children's play at war memorials and other dark heritage sites}

In particular, children's exploratory play behavior needs further conceptualization in tourism studies, as noted by Poria and Timothy (2014) and Kerr and Price (in press). Exploratory play behavior is one means by which children engage with sites in ways that differ from adults (Kerr \& Price, in press). This behavior may include individual or groups of children who test hypotheses, role-play unfamiliar situations, test boundaries of activities or spaces, and compete with each other (Sutcliffe \& Kim, 2014, p. 9). This boundary testing may look like play in inappropriate spaces. As Sutcliffe and Kim (2014) argued:

"Research tends to examine how accompanying adults interact with children, teach children about appropriate behaviour in heritage/museum venues, or types of exhibits favoured by children. These approaches assume children to be adults in the making, and 
rarely approach the child's visit in the way that a child likely would, and that is from the aspect of play." (p. 3)

A few researchers have taken initial steps to study this issue. Bowman and Pezzullo (2010) and Carr (2010) both noted children "playing war" at battlefield sites. Knudsen (2011) noted children "playing music" at Birkenau concentration camp. And, Sutcliffe and Kim (2014) observed and interviewed children engaging with interpretation at a cultural heritage museum. Recently interviewing children who visited heritage sites in Ireland, Roche and Quinn (2016) found that children most fondly remembered those sites where they could "run around and climb a lot" (p. 7). Such play behavior gave rise to the debate we analyzed in social media.

\section{Social media comments in tourism research}

In tourism research, analyses of social media comments from sites like TripAdvisor.com allow researchers to determine tourists' opinions about topics such as risk-taking as travelers and historical authenticity of tourism destinations (e.g., Björk \& Kauppinen-Räisänen, 2012; Mkono, 2013). The emotional disclosures included in online comments have proven fruitful for tourism researchers (Munar \& Ooi, 2012). Ooi and Munar (2013) note that while tourist-generated content encourages high levels of interactivity and participation, it also has potential to "spread globally, like viral diseases" (p. 161).

A few studies have included social media comments relating to dark heritage sites. In one example, Ferguson, Piché, and Walby (2015) analyzed over 600 TripAdvisor.com comments critiquing interpretation and exhibits at Canadian penal history museums. Similarly, Ooi and Munar (2013) analyzed TripAdvisor.com comments critiquing visitor experience at Ground Zero (site of the 9/11 World Trade Center attacks in New York City). They found that online commenters created their own interpretations of the site, and they declared their own rules of 
behavior. Commenters' rules and interpretations conflicted and led to lively discussion, but not to consensus.

Our study differs from prior studies of tourism-related online comments. While prior studies included online expressions about tourists' own experiences at a site, our study solely includes comments generated by an image of other people's experiences: children pictured climbing on a war memorial. Also, instead of scrutinizing comments on a travel review site, we analyzed opinions expressed on the news site Reddit.

\section{Expressing opinions through social media}

Social media allows for individuals worldwide to view content and express opinions in both synchronous and asynchronous conversation (Baym, 2015; Litvin, Goldsmith, \& Pan, 2008). On social media, people may feel more inclined to relate their true feelings, attitudes, perspectives, and judgments in public view, under the relative anonymity of a user name (Kucher, SchampBjerede, Kerren, Paradis, \& Sahlgren, 2015). Online commenters feel free to express their opinions and engage in debates with back and forth patterns of incivility accepted as the norm (Coe, Kenski, \& Rains, 2014). Social media allows for individuals to express their views, often unfiltered and with vigor.

Stance, a concept from linguistics, refers to the "attitudes, feelings, perspectives, or judgments" communicated in text or human conversation (Kucher et al., 2015, p. 94). Beyond merely expressing emotional subjectivity, the act of taking a stance involves both evaluation and interaction (Kucher et al., 2015). Keisling (2011) defines three axes of stance: alignment, affect, and investment. Alignment refers to the communicator's agreement or disagreement with others. Affect describes the polarity of stance, encompassing the assessment or judgment of the topic 
under discussion. Investment describes level of conviction (e.g., "Would they defend their claims and opinions to the death?”) (Keisling, 2011, p. 5).

Researchers use stance analysis to study online comments reflecting individual judgments about controversial topics, including abortion, marijuana use, and media influence on body image (e.g., Altshuler, Gerns Storey, \& Prager, 2015; Krauss, Grucza, Beirut, \& Cavazos-Rehg, 2015; Paraskeva, Lewis-Smith, \& Diedrichs, 2015). Analysis may include providing a "temporal overview of stance," "retrieving the corresponding text data relevant to stance phenomena, or analyzing the occurrences of stance expressions" (Kucher et al., 2015, p. 94). In our study, we examined the Reddit comments to determine what - if any — stance commenters would take about children playing at a war memorial.

\section{Methods}

\section{Evidence under study}

We studied comments on the social media site Reddit, which describes itself as the "Internet's front page," because the Reddit post of this photograph received national notoriety (MetalClocker, 2015). Known for its democratic values, Reddit allows the online community to make website modifications; it allows any member to create a community or /subreddit, and it encourages comments on every story. Also, Redditors, as Reddit members are called, upvote stories and discussions that they consider important enough to appear at the top of the front page.

Reddit has a large and global user base. For example, on one day (April 6, 2016) Reddit claimed that it had " 11,613 active communities," consisting of "3,393,390 logged in Redditors," who "voted on 32,411,073 stories or comments" (https://www.reddit.com/about/).

In addition to upvoting, Reddit's openness allows posts to spread rapidly. Reddit does not require membership or registration to view posts or comments. However, users must register and 
create usernames in order to contribute their own content. Redditors choose their own screen names and how much information they reveal about themselves. To protect commenters' anonymity, Reddit's content policy prohibits users from posting personal and confidential information (https://www.reddit.com/help/contentpolicy).

The sample for this study includes the 150 comments that received the most upvotes from Redditors (indicating that they considered these the most interesting comments) as collected on April 8, 2015. It is worth noting that reposts of this image on other sites spurred additional online comments. However, we followed this original story from its initial post, until the comments stopped after 15 days. We then used screen capture software to collect the upvoted top posts. Comments have sporadically appeared since data collection; however, we captured the initial flood of comments while the topic remained in the news.

\section{Ethical safeguards}

Before data analysis began, we contacted our University's Institutional Review Board, which responded that it need not approve a study of comments posed publicly online. Further, this study does not qualify as human subjects research, since we did not interact with humans, but merely collected and analyzed the public information that they left behind (Moreno, Goniu, Moreno, \& Diekema, 2013). According to Moreno et al. (2013) social media users logically lack a legitimate expectation of privacy in materials posted publically, and "this has become a generally accepted principle of law" (p. 710). Similar to Ferguson et al. (2015), we elected to protect the anonymity and confidentiality of Redditors by not displaying their user names; rather, we assigned them randomly ordered user code numbers.

\section{Data analysis}


After reading the comments as a whole multiple times, we entered each comment individually into a qualitative software program. We made the initial analytic decision to consider these data as individual comments, situated within discourse. To keep the research question central to our analysis, we specifically noted what individuals said about children's behavior at this (or any) memorial, retrieving and analyzing the occurrences of stance expressions (Krippendorff, 2013; Kucher et al., 2015). Yet at the same time, we realized that all discourse makes sense within a "chain of communication... understood against the background of other concrete utterances on the same theme, a background made up of contradictory opinions, points of view, and value judgments" (Bakhtin, 1935/1981, p. 281). With that in mind, we made the decision to include username as an attribute for each comment, so that we could determine which commenter said what and follow the thread of topics. This allowed us to understand the context of comments when the words themselves were not specific (e.g., "I went there" refers to the Pentagon National Memorial, when considered in context of conversation).

\section{Directed content analysis}

We began with a codebook derived from the conceptual framework that guides our research on children's experiences at dark sites. This framework allowed us to identify, define, operationalize, and explore relationships between concepts (Veal, 2006, p. 55). Using our initial concepts, we employed a directed content analysis approach, based on procedures outlined by Hsieh and Shannon (2005) and Potter and Levine-Donnerstein (1999). More structured than conventional approaches, the goal of directed content analysis is to "validate or extend conceptually" an existing theoretical framework or theory (Hsieh \& Shannon, 2005, p. 1281). With this approach, we applied initial codes to the data. Then, we further analyzed any content not adequately captured by initial coding, to determine the necessity of new categories or 
subcategories (Hsieh \& Shannon, 2005; Krippendorff, 2013). The two members of the research team independently coded 20 comments, then met to refine our codes and our codebook. As one researcher continued to code the remaining comments, she identified additional codes and subcodes (e.g., war stories, examples from other dark sites, role of the commenter).

\section{Verification of findings}

We used several approaches to verify our findings. Data matrices allowed the researchers to determine the prevalence of vehement posts. We charted all comments containing behavioral expectations by level of investment, 1-3, in a technique suggested by Miles, Huberman, and Saldaña (2014). Level one represented a mild level of investment, and level three represented extreme investment. Level one included short and mildly stated opinions; level two included moderately stated logical reasoning for opinions; level three included vivid allegories, imagery, insults, profanity, and threats. After one member of the research team charted the comments, the coauthor reviewed and weighted each comment independently. Agreement was $100 \%$. We used a data matrix to compare these comments side by side, which provided evidence of extreme comments. Extreme comments against children's play behavior far outnumbered extreme comments on behalf of play, and they reflected the opinions of multiple individuals. Then, using techniques suggested by Miles et al. (2014), we moved beyond initial coding to cluster related "rules comments" by rationale.

Finally, we checked for counterevidence in two ways. First, the two researchers independently coded comment subsamples and conferenced to consensus. Then, following Lincoln and Guba (1985, p. 308), we peer-reviewed our coding and findings with colleagues outside the study, whose disciplinary backgrounds differ from ours.

\section{Findings}


We start by noting commenters' self-identified roles. Then, we discuss what commenters said about children's behavior at memorials, and what their rationales reveal about the meaning of war memorials. To retain the vitality of Internet conversation, comments appear here as they were written, with one exception: profanity appears with asterisks replacing some letters.

\section{Commenters' self-identified roles}

The 150 comments selected represented the views of 131 individuals (i.e., they posted under 131 unique usernames). While Reddit only provides username information, some people self-identified within their comments. To illustrate, a self-identified family member of a veteran left the following comment: "...I have personally witnessed this, as my dad was a veteran (User 9). Others acknowledged their family and professional roles, including parents, students, veterans, active military, and others. When commenters self-identified, we include that information with the comment.

\section{What commenters said about children's play behavior at memorials}

Similar to Ooi and Munar's (2013) study of Ground Zero, one-third of the commenters on this photograph quickly took sides. This recurrent stance-taking led us to enhance our conventional analysis by adopting Keisling's (2011) definitions for stance analysis, considering commenters' affect, alignment, and investment. Fifty-six comments, representing 51 individual users, expressed a stance or belief about the children's behavior in this picture or at war memorials in general. Commenters aligned their opinions with one of two directly opposing views: children should play at war memorials and children should not play at war memorials. Of those, onethird of comments $(n=16)$ condoned children's play behavior at war memorials, while two-thirds $(n=40)$ did not approve. One commenter admitted support for both sides of the debate. 
Commenters expressed their opposing viewpoints in comments along a spectrum of mild to extreme investment (i.e., personal conviction).

While commenters debated the rules for children playing at war memorials, a parallel dispute arose about whether play itself could be a meaningful experience. One commenter stated: "I wouldn't tell kids to go play on something like this but if they were going to do it anyway I would attempt to bring some meaning to it" (User 44).

Others disagreed, some forcefully: "I would teach them, as parents are supposed to do, that there are times to play and times to be serious There should be no "doing it anyway" (User 10). "U $[$ sic $]$ don't try to bring some meaning to it. $\mathrm{F}^{* *}$ king stop them" (User 36$)$. While the alignment of each commenter is clear, it is unclear whether the "you" mentioned by User 36 refers to the prior commenter specifically, or to parents in general.

\section{Shared rationales reveal the meanings of war memorials}

Although commenters on each side of the debate argued, sometimes forcefully, they unified in support for what war memorials represent. Table 1 illustrates the rationales used by each side of the argument.

(Table 1) 
As Table 1 shows, both sides indicated agreement that war memorials symbolize a place to remember the service of deceased soldiers and veterans, a place to generally show respect or do what is right, or a place to appreciate art. Interestingly, the view that a memorial represents an educational experience received support only from those in favor of children's exploratory play. In spite of shared rationales, commenters aligned on opposite sides of the question of children's behavior at memorials. The following sections illustrate the shared rationales and the opposing viewpoints they represent.

Because soldiers died

Commenters defending and repudiating play cited the rationale that war memorials represent a place to remember soldiers who died. Consider these comments typifying each side of the debate.

"Isn't that exactly what those soldiers died for." For commenters on one side of the debate, soldiers died so that children might have the freedom to play at war memorials. One commenter recalled how a tour guide corrected him on a trip to Omaha Beach (site of the D-Day invasion):

"I got a tour in Normandy and when we got the beaches of d-day [sic] it looked like any other beach with families and kids and I asked the guide why they allow this and it isn't like closed off in memorial of the soldiers who died. and he totally put me in my place and said 'isn't that exactly what those soldiers died for"” (User 15)

A self-identified veteran agreed with the rationale that soldiers died so that children might play at memorials:

"I don't know. I've been in the military, and I've helped a friend breathe their last breath as they looked in my eyes. The older I get the more I'm inclined to think of children as 
the point of their deaths, the point of their suffering...and if the insufferable little $\mathrm{s}^{* *}$ ts are wont to crawl all over a representation of these things I want them to be able to. It's not generally acceptable in today's culture, but I just see their naive play as something that would make my ghost smile as they ignore custom and leave a muddy footprint on my statue's face. We died for a reason, and for me at least, this was it.” (User 24)

Both of these commenters seemed to question the general acceptability of children playing at war memorials. Yet, they and others agreed that children's play at war memorials represents a precious freedom purchased with soldiers' lives. In contrast, critics of children's play insisted on solemn and respectful behavior. They left a variety of comments, from metaphorical comparisons to strongly worded criticisms.

“You would not let kids be raucous and run around at a funeral." One commenter's logic compared war memorials to graveyards or funerals:

"You would not let kids be raucous and run around at a funeral. The same should be observed at memorials[.] No one will be hurt by your kids being quiet and respectful even people who like seeing kids play on memorials. But it is very likely that someone will be upset by your kids crawling all over the memorial where people come to remember their dead friends." (User 9)

Other commenters left vehement remarks. One person ranted about future implications for children whose parents allow them to play on memorials:

"The statue isn't just a memorial, it's a visual representation of anguish and loss. For kids to play on it is one thing, but for the parents to think of the idea is beyond distasteful, and those kids are going to grow up to be inconsiderate $\mathrm{p}^{* *}$ cks. They'll grow up never thinking before they act and we all suffer for it. You see them everyday [sic] on your drive to work, in the grocery store, in the movie theater, and [they] probably live right 
next to you. This world would be a completely different place if people would take 5 seconds before they do something to see if they are inconveniencing or offending someone else.

No one in my family was ever in the military, so I don't hold their sacrifice as sacred as some others who have had family fight and die, however, telling my child to go play on a memorial statue is something I'd never even think about doing." (User 38)

This commenter claimed no personal connection to soldiers who died, yet the comment conveys emotion and a very personal belief: parents who allow children to climb on memorials violate important norms.

Because of general respect or feeling of what is right

Commenters on both sides of the debate also noted that war memorials command respect. While only $6 \%$ of play supporters cited respect, $55 \%$ of critics used this rationale. Consider these comments from each point of view.

It "felt actually very appropriate." Similar to a previous commenter, one person who supported children's play behavior at war memorials recalled a visit to the beaches of Normandy:

"We visited Oklahoma and Juno beach, and they are not that wide. There must have been bodies piled up in layers. It was a very emotional visit for our whole family. However getting back to my point, seeing kids run on the beach and flying kites felt actually very appropriate.” (User 1)

Like some others, this commenter chose to recollect her own visit to a war memorial rather than pass judgment on the children in the photograph.

“It's extremely disrespectful." Several commenters criticized children's play at war memorials as disrespectful or "feeling" wrong. The levels of investment in these comments ranged from mild to extreme. Several commenters on this side of the debate referred to 
hypothetical situations, and two related their own experience. One commenter imagined how he might feel as a tourist witnessing children playing on an Operation Enduring Freedom (OEF) memorial, "Watching some kids climb on an OEF monument that I traveled to so I could pay my respects would infuriate me" (User 14). Another commenter expressed his outrage:

"These kids are literally stepping on and rubbing their *ss on a depiction of people in anguish. It's one thing to climb on top of a rock with names, it's another to literally put your foot on top of a face in anguish. It's extremely disrespectful.” (User 45)

According to these commenters and others, children's play behavior at war memorials disrespects the memorial, the image it depicts, and the other visitors present.

Because veterans served

Several commenters agreed that a memorial represents the service of veterans. Because veterans served was the most popular rationale among the commenters who supported play at memorials, with $31 \%$ of the comments on that side of the issue.

"Sometimes the laughter of children is the best memorial." Those who supported play as honoring veterans left comments ranging mild to extreme. One moderate commenter explained her stance:

"The way I see it, it's a choice whether or not to be offended by something like this. The consequences of being offended are that they feel resentment for the kids $\&$ their parents, and the kids feel confused for being chastised for having innocent fun, causing a sense of alienation between these generations. On the other hand, the consequences of choosing not to be offended are that the kids enjoy their play, and the vets can be happy for them." (User 13) 
Like others, she surmised that veterans would condone play, although she did not identify herself as a veteran. Another commenter incorporated a secondhand story to fortify enthusiastic defense of children playing at memorials:

"My wife spent a summer in DC teaching for a college program. Since her students were busy during the day she'd go down to the Mall (the big green space between Congress and the Lincoln Memorial, for those of you less familiar with DC) most days.

One particularly hot day she's sitting on a bench an the WWII memorial reading a book while some kids play in the fountain. Now, there are signs telling people to be respectful of the memorial but, unlike Vietnam, the WWII memorial is a lot more like a public plaza and a lot less like a national gravesite. In any case, one of the National Park Service personnel approached the kids and told them to get out of the fountain only to be dressed down by some 90 year old veteran who told him that "I didn't swim ashore at Omaha Beach so you could tell kids not to play in a fountain." Sometimes the laughter of children is the best memorial to a great generation." (User 20)

"I would be annoyed." While some commenters viewed children's laughter and play as a veteran's legacy to the next generation, others rejected this interpretation. A self-described Afghanistan war veteran targeted disrespectful parents allowing their children to cavort at a memorial:

"Some day in the future when I'm old and visiting an Afghan War monument, reflecting on the people who went to oblivion there for a war of murky political gain and shady moral backing, I would be annoyed if I saw children running and climbing all over the monument. Not annoyed at the children, per se, but at their parents for their lack of respect... I'll be thinking about the fact that I could have been that boy whose body was torn apart.” (User 30) 
Another used profanity and implied violence, "Reading this makes me want to $b^{* *}$ ch slap those kids off of it" (User 37). Young children's play at this war memorial enraged this virtual onlooker, who felt free to express his feelings in an online comment. Another commenter's word choice echoed his frustration, "How do you think people get more respect for veterans? by, literally, letting your kids climb on the memorials in front of them? The statues are of people being shot and dying..! don't even..." (User 39).

Despite the passion evident in the comments about veterans, self-described veterans took both sides of the debate, revealing that commenters' assumptions about veterans may not echo the feelings of veterans themselves.

Because this is art

Finally, several commenters invoked the concept of art to support their condemnation or encouragement of children's hands-on exploration. Below, we present examples from both viewpoints.

"In my head, this is beautiful." One commenter remarked that children playing on a memorial enhanced its aesthetic appeal, "in my head, this is beautiful. it's almost even more artistic with the kids climbing on it. a suffering past meets its free and playful future" (User 12). In witnessing the sculpture's capacity to engage children, this commenter drew a parallel to the freedom of a peaceful future after war.

“Look but don't touch," or "Your kid is going to end up dead.” Commenters who thought that children should stay off the artwork left comments that ranged from mild to extreme. In addition to remarking that sculptures are not designed to be climbed upon, commenters warned of damage to the sculpture and threats of injury or even death to children who play there. Milder comments included "look but don't touch" sentiments: 
"To me, memorials get the "look but don't touch" sort of status that I give statues or art. Sure, you could climb all over the Pieta statue or the Lincoln memorial [sic] and make it poetic and all, but you're still climbing over something that wasn't intended for that." (User 46)

Several commenters voiced warnings to stay off the statuary, citing that children could offend many people, hurt themselves or the sculpture, or even die. Some comments described children's deaths:

"letting kids climb on statuary is a great way to break it get killed. Seriously. This is a huge problem in cemeteries and why you hear about gravestones falling on children and killing them. They climb all over them and it breaks or falls with them.” (User 50)

This commenter agreed:

"This reminds me of a little girl who was killed when a statue fell on her. This was in San Francisco's Fisherman's Wharf area. A store had a massively heavy sculpture/statue out front and some kid started climbing on it and it tipped over and crushed the kid.

Keep your kids off things that are not playground equipment unless you are comfortable with the chances your kid is going to end up dead." (User 47)

These commenters sought to convince others of their views by using vivid imagery of children dying. Below, we summarize our findings.

\section{Summary}

Hartmann notes, "long before dark-tourism research began, memorials to wars won or lost and in honor of their victims dotted the cultural landscape" (2014, p. 176). Certainly, adults may have multiple motivations for visiting war memorials. These might include religious pilgrimage, feelings of national fervor, or compulsions to remember or to revise history (Kerr \& Price, in press; Carr, 2010; Collins-Kreiner, 2015; Seaton, 2002; Stone, 2013; Stone \& Sharpley, 2013). 
For some, a visit may symbolize a personal confrontation with one's own inevitable demise (Stone, 2013). Or, an adult might visit a memorial as tangential side trip, unconnected to a primary tourism destination (Ashworth \& Isaac, 2015; Walter, 2009). On the other hand, young children such as those portrayed in the photograph lack agency to choose their travel destinations. They may seek different ways to explore a memorial, as several authors have observed (Kerr \& Price, in press; Bowman \& Pezzullo, 2010; Carr, 2010; Khoo-Lattimore, 2015; Knudsen, 2011; Roche \& Quinn, 2016; Sutcliffe \& Kim, 2014).

How children explore a memorial may be influenced by what adults nearby communicate, verbally or non-verbally. While few would disagree that one should respect memorials and those memorialized, contradictory norms for respectful behavior emerged here. Similar to Ooi and Munar's (2013) findings, commenters in this study could not reach a consensus about appropriate behavior for children in this war memorial setting. While commenters disagreed on behavioral rules, they seemed to agree about what war memorials represent: soldiers' deaths, veterans' service, general places to show respect, or artistic representations. A smaller percentage of commenters stated that war memorials represent an educational experience. Many more commenters took no obvious stance but actively followed the discussion over weeks, leaving us to surmise that the topic is significant to the public at large.

A study of web comments has several limitations, including the inability to ask probing questions, the inability to verify personal details of participants other than what they have provided, and the lack of access to nonverbal cues (Björk \& Kauppinen-Räisänen, 2012; Ferguson et al., 2015). Nevertheless, this sample represented a unique opportunity to better understand the public's views of children's behavior at war memorials and to gain a deeper 
understanding of what those memorials represent. We now turn to the question of what this all means for those interested in child tourists.

\section{Conclusions and implications for future research}

While notably few academics have shown interest in children's behavior at memorials, the youthful exploratory behavior depicted in this photo ignited a heated public debate. Controversy about children's behavior at memorial sites seems to recur, most recently in the widespread public attention to children playing Pokémon Go at memorials (Bromwich, 2016). A recent Google search of the phrase, “children playing at memorial," produced 39,700,000 results. Clearly, this provocative topic offers a rich harvest for interested researchers, who might choose to pursue several paths.

First, one cannot ignore the context of this study. Shared rationales evident on both sides of a heated debate indicate cultural values held in common. For example, commenters seemed to want the best for veterans and value their service, yet at the same time tended to generalize the opinions of veterans, instead of thinking about them as individuals. However, we found comments from self-identified veterans on both sides of the debate. We do not know whether the focus on veterans stems from the title of the Reddit post ["Parents letting their kids play on the "Vietnam Women's Memorial" Right in Front of Veterans"] or the presumed veteran depicted next to the children in the photograph. Further studies could more deeply explore the nationalist context of war memorial tourism in the United States, as well as memorial tourism contexts in other countries.

In addition, further questions deserve exploration. How might future research best uncover shared behavioral norms? And, whose values do these norms reflect? As educators and 
interpreters grapple with these complex questions, studying online debates offers one path toward greater understanding of deep-seated feelings and beliefs.

Importantly, the children absent from this conversation have much to tell curious researchers. How might visiting children know that soldiers died? Prior research has discussed children's incomplete understanding of death as one way in which their tourism experience differs from that of adults (Kerr \& Price, in press; 2016). How do children come to understand the rules at a memorial? What signals might have indicated to these children that this war memorial was an appropriate place to play?

On a recent trip to this Vietnam Women's Memorial with a group of middle school students, we asked the adolescents why they thought young children might climb across the bronze figures. "Oh, we know that. This is like the ones in the zoo!" they exclaimed. They went on to explain that at a zoo near their community, young children are encouraged to play on animal-shaped sculptures of comparable size and material, similarly displayed in a plaza without a fence or barrier rope. "At the zoo we climb all over them!" explained the teenagers, "so little kids would think it was okay to climb here, too." The teens' spontaneous analysis hints at what others have set forth: children's perspectives are uniquely theirs. No matter how intensely felt, adult views simply cannot capture younger visitors' experiences. This brief anecdote illustrates the expertise children provide in deepening our (adult) understanding of their experiences. Future research should invite children to actively participate or even design, collect, and analyze information about their own experiences, as others have suggested (Christensen \& James, 2008; Pinter, 2014; Pinter \& Zandian, 2014; Pinter \& Zandian, 2015).

This exploratory study represents a first step in understanding how the public views children's behavior at war memorials. How might those views influence children's experiences? 
How might they affect adult interactions with young visitors and their parents? In some instances, these comments depict a frightening scenario. As site managers resolve how to address Pokémon Go and each successive phenomenon, deep-seated adult beliefs revealed here warrant consideration. 


\section{Acknowledgements}

The authors acknowledge Matthew Munson for permission to reprint this photograph and Amy Marsh for bringing the original post to our attention. We also thank Dr. Andrew Oberg for technical assistance with data collection and Dr. Jennifer Lin Russell and Dr. Lauren B. Collister for their helpful critiques of early drafts of this manuscript. 


\section{References}

Altshuler, A. L., Gerns Storey, H. L., \& Prager, S. W. (2015). Exploring abortion attitudes of US adolescents and young adults using social media. Contraception, 91, 226-233. doi: 10.1016/j.contraception.2014.11.009

Ashworth, G. J., \& Isaac, R. K. (2015). Have we illuminated the dark? Shifting perspectives on “dark" tourism. Tourism Recreation Research, 40(3), 316-325.

Bakhtin, M. (1981). The dialogic imagination: Four essays. (C. Emerson \& M. Holquist, Trans.). Austin, TX: University of Texas Press. (Original work published 1935)

Baym, N. (2015). Personal connections in the digital age (2 ${ }^{\text {nd }}$ ed.). CambridgeEngland: Polity.

Biran, A., Poria, Y., \& Oren, G. (2011). Sought experiences at (dark) heritage sites. Annals of Tourism Research, 38(3), 820-841.

Björk, P., \& Kauppinen-Räisänen H. (2012). A netnographic examination of travelers’ online discussions of risks. Tourism Management Perspectives, 2(3), 65-71.

Bowman, M. S. \& Pezzullo, P. C. (2010). What's so 'dark' about 'dark tourism?:' Death, tours, and performance. Tourist Studies, 9(3), 187-202.

Bromwich, J. E. (2016, July 12). Where Pokémon should not go. The New York Times. Retrieved from http://www.nytimes.com/2016/07/13/technology/where-pokemon-should-notgo.html

Carr, G. (2010) Shining a light on dark tourism: German bunkers in the British Channel Islands. Public Archaeology, 9(2), 64-84.

Christensen, P., \& James, A. (Eds). (2008) Research with children: Perspectives and practices London, England: Routledge. 
Coe, K., Kenski, K., \& Rains, S. A. (2014). Online and uncivil? Patterns and determinants of incivility in newspaper website comments. Journal of Communication, 64, 658-679.

Collins-Kreiner, N. (2015). Dark tourism as/is pilgrimage. Current Issues in Tourism, 1-5. Advance online publication

Facebook rant on parenting, respecting veterans goes viral. (2015, July 22). KRMG News. Retrieved from http://www.krmg.com/news/news/national/facebook-rant-parentingrespecting-veterans-goes-v/nm4sY/

Ferguson, M., Piché, J., \& Walby, K. (2015). Bridging or fostering social distance? An analysis of penal spectator comments on Canadian penal history museums. Crime Media Culture, $11(3), 357-374$.

Foley, M., \& Lennon, J. (1996). Editorial: Heart of darkness. International Journal of Heritage Studies, 2(4), 195-197.

Frost, W., \& Laing, J. H. (2016). Children, families and heritage. Journal of Heritage Tourism, 1-6. Advance online publication. doi: 10.1080/1743873X.2016.1201089

Hartmann, R. (2014). Dark tourism, thanatourism, and dissonance in heritage tourism management: New directions in contemporary tourism research. Journal of Heritage Tourism, 9(2), 166-182.

Hsieh, H. F., \& Shannon, S. E. (2005). Three approaches to qualitative content analysis. Qualitative Health Research, 15(9), 1277-1288.

Keisling, S. (2011, April). Stance in context: Affect, alignment, and investment in the analysis of stance taking. Paper presented at the iMean conference, Bristol, England. Retrieved from http://s3.amazonaws.com/academia.edu.documents/35655471/Kiesling-StanceinContextiMean- 
pub.pdf?AWSAccessKeyId=AKIAJ56TQJRTWSMTNPEA\&Expires=1471625067\&Sig nature $=\mathrm{qNnK} 7 \mathrm{ogXCxnItic} \% 2 \mathrm{~B} 0 \mathrm{~A} \% 2 \mathrm{BIGnOM} 11 \mathrm{~A} \% 3 \mathrm{D} \&$ response-contentdisposition=inline $\% 3 \mathrm{~B} \% 20$ filename $\% 3$ DStance_in_context_Affect_alignment_and_i.pdf

Kerr, M. M., \& Price, R. H. (in press). "I know the plane crashed:” Children's perspectives in dark tourism. In P. R. Stone, R. Hartmann, T. Seaton, R. Sharpley, \& L. White (Eds.), The Palgrave MacMillian handbook of dark tourism studies. London, UK: Palgrave Macmillian.

Kerr, M. M., \& Price, R. H. (2016). Overlooked encounters: Young tourists' experiences at dark sites. Journal of Heritage Tourism, 11(2), 177-185.

Khoo-Lattimore, C. (2015). Children on board: Methodological challenges, concerns and clarifications when including young children's voices in tourism research. Current Issues in Tourism, 18(9), 845-858.

Knudsen, B. T. (2011). Thanatourism: Witnessing difficult pasts. Tourist Studies, 11(1), 55-72.

Krauss, M. J., Grucza, R. A., Bierut, L. J., \& Cavazos-Rehg, P. A. (2015). “Get drunk. Smoke weed. Have fun.:" A content analysis of tweets about marijuana and alcohol. American Journal of Health Promotion. Advance online publication. doi: 10.4278/ajhp.150205QUAL-708

Krippendorff, K. (2013). Content analysis: An introduction to its methodology ( $3^{\text {rd }}$ ed.). Los Angeles, CA: Sage.

Kucher, K., Schamp-Bjerede, T., Kerren, A., Paradis, C., \& Sahlgren, M. (2015). Visual analysis of online social media to open up the investigation of stance phenomena. Information Visualization, 15(2), 1-24. 
Lincoln, Y. S. \& Guba, E. G. (1985). Naturalistic inquiry. Newbury Park, CA: Sage Publications.

Litvin, S. W., Goldsmith, R. E., \& Pan, B. (2008). Electronic word-of-mouth in tourism management. Tourism Management, 29, 458-468. doi: 10.1016/j.tourman.2007.05.011

MetalClocker. (2015). Parents letting their children play on the "Vietnam Women's Memorial" right in front of veterans [Reddit post]. Retrieved from https://www.reddit.com/r/pics/comments/304g58/parents_letting_their_children_play_on the/

Miles, M. B., Huberman, A. M., \& Saldaña, J. (2014). Qualitative data analysis: A methods sourcebook ( $3^{\text {rd }}$ ed.). Los Angeles, CA: Sage.

Mkono, M. (2013). African and Western tourists: Object authenticity quest? Annals of Tourism Research, 41, 195-214.

Moreno, M. A., Goniu, N., Moreno, P. S., \& Diekema, D. (2013). Ethics of social media research: common concerns and practical considerations. Cyberpsychology, Behavior, and Social Networking, 16(9), 708-713.

Munar, A. M., \& Ooi, C. S. (2012). The truth of the crowds: Social media and destination management. In L. Smith, E. Waterton, \& S. Watson (Eds.), The cultural moment in tourism (pp. 255-273). London: Routledge.

MyFoxDC.com Web Producer. (2015, March 25). Photo gone viral shows children playing on Vietnam Women's Memorial-- while veterans watched. Fox 5. Retrieved from http:/www.fox5dc.com/news/1690209-story 
Ooi, C. S., \& Munar, A. M. (2013). Digital social construction of a tourist site: Ground Zero. In A. M. Munar, S. Gyimóthy, \& L. Cai (Eds.), Tourism social media: Transformations in identity, community, and culture (pp. 159-175). Bingley, England: Emerald.

Paraskeva, N., Lewis-Smith, H., \& Diedrichs, P. C. (2015). Consumer opinion on social policy approaches to promoting positive body image: Airbrushed media images and disclaimer labels. Journal of Health Psychology. Advance online publication. doi: 1359105315597052

Pearson, M. (2015, March 26). Photo of children climbing on Vietnam memorial causes anger. CNN. Retrieved from http://www.cnn.com/2015/03/26/living/vietnam-memorial-viralphoto-feat/

Pinter, A. (2014). Child participant roles in applied linguistics research. Applied Linguistics, 35(2), 168-183.

Pinter, A., \& Zandian, S. (2014). "I don't ever want to leave this room:” Benefits of researching ‘with’children. ELT journal, 68(1), 64-74.

Pinter, A., and Zandian, S. (2015) "I thought it would be tiny little one phrase that we said, in a huge big pile of papers": Children's reflections on their involvement in participatory research, Qualitative Research, 15(2), 235-250.

Poria, Y., Reichel, A., \& Biran, A. (2006). Heritage site perceptions and motivations to visit. Journal of Travel Research, 44, 318-326.

Poria, Y., \& Timothy, D. J. (2014). Where are the children in tourism research? Annals of Tourism Research, 47, 93-95. 
Potter, W. J., \& Levine-Donnerstein, D. (1999). Rethinking validity and reliability in content analysis. Journal of Applied Communication Research, 27(3), 258-284. doi: $10.1080 / 00909889909365539$

Roche, D., \& Quinn, B. (2016). Heritage sites and schoolchildren: Insights from the Battle of the Boyne. Journal of Heritage Tourism. Advance online publication. doi: 10.1080/1743873X.2016.1201086

Seaton, A. (1996). Guided by the dark: From thanatopsis to thanatourism. International Journal of Heritage Studies, 2(4), 234-244.

Seaton, A. (2002). Thanatourism's final frontiers? Visits to cemeteries, churchyards and funerary sites as sacred and secular pilgrimage. Tourism Recreation Research, 27(2), 73-82.

Small, J. (2008). The absence of childhood in tourism studies. Annals of Tourism Research, 35(3), 772-789.

Stone, P. R. (2006). A dark tourism spectrum: Towards a typology of death and macabre related tourist sites, attractions and exhibitions. Tourism: An Interdisciplinary International Journal, 54(2), 145-160.

Stone, P. R. (2013). Dark tourism scholarship: A critical review. International Journal of Culture, Tourism, and Hospitality Research, 7(30), 307-318.

Stone, P. R., \& Sharpley, R. (2013). Deviance, dark tourism, and “dark leisure:” Towards a (re)configuration of morality and the taboo in secular society. In S. Elkington \& S. Gammon (Eds.), Contemporary perspectives in leisure: Meanings, motives and lifelong learning (pp. 54-64). London: Routledge.

Sutcliffe, K., \& Kim, S. (2014). Understanding children's engagement with interpretation at a cultural heritage museum. Journal of Heritage Tourism, 9(4), 332-348. 
Sather-Wagstaff, J. (2011). Heritage that hurts: Tourists in the memoryscapes of September 11. Walnut Creek, CA: Left Coast Press.

Timothy, D. J., \& Boyd, S. B. (2006). Heritage tourism in the 21 st century: Valued traditions and new perspectives, Journal of Heritage Tourism, 1(1), 1-16.

Uzzell, D., \& Ballantyne, R. (2008). Heritage that hurts: Interpretation in a postmodern world. In G. Fairclough, R. Harrison, J. H. Jameson \& J. Schofield (Eds.) The Heritage Reader (pp. 502-513). New York, NY: Routledge.

Veal, A. J. (2006). Research methods for leisure and tourism: A practical guide ( $\left.3^{\mathrm{rd}} \mathrm{ed}.\right)$. Harlow, England: Prentice Hall.

Walter, T. (2009). Dark tourism: Mediating between the dead and the living. In R. Sharpley \& P. R. Stone (Eds.), The darker side of travel: The theory and practice of dark tourism (pp. 39-55). Bristol, England: Channel View Publications.

Wight, C., \& Lennon, J. (2002). Towards an understanding of visitor perceptions of 'dark' attractions: The case of the Imperial War Museum of the North, Manchester. Journal of Hospitality and Tourism, 2(2), 105-122. 
Table 1. Common rationales and percentages of associated comments on each side of debate $(\mathrm{n}=56)^{\mathrm{a}, \mathrm{b}}$

\begin{tabular}{lll}
\hline Rationale & $\begin{array}{l}\text { Children should play at } \\
\text { war memorials } \\
(\mathrm{n}=16)^{\mathrm{c}} \\
\%\end{array}$ & $\begin{array}{l}\text { Children should not } \\
\text { play at war memorials } \\
(\mathrm{n}=40)^{\mathrm{d}} \\
\%\end{array}$ \\
\hline $\begin{array}{l}\text { Because soldiers died... } \\
\begin{array}{l}\text { Because of general feelings about respect } \\
\text { and what is right... }\end{array}\end{array}$ & .06 & .25 \\
Because veterans served... & .31 & .08 \\
Because this is art or a sculpture... & .06 & .18 \\
Because it is educational... & .13 & -
\end{tabular}

Note: ${ }^{a} \mathrm{n}$ refers to total comments expressing a behavioral expectation.

${ }^{\mathrm{b}}$ Percentages do not equal 100 , because not every comment listed a rationale for stated behavioral expectation, and some comments listed multiple rationales.

${ }^{\mathrm{c}} \mathrm{n}$ refers to total comments expressing expectation that children should play at memorials.

${ }^{\mathrm{d}} \mathrm{n}$ refers to total comments expressing expectation that children should not play at memorials. 


\section{Figure caption}

Figure 1. (C) [Matthew Munson]. Reproduced by permission. 